\title{
Editorial
}

\section{The Basel Committee on Banking Supervision report on customer due diligence, October 2001}

The events of 11th September in the USA, with the resultant focus on terrorist financing and the ensuing global discussion on removing financial support from terrorist networks, have given added significance to the new report published in October on Customer Due Diligence from the Basel Committee on Banking Supervision's Working Group on Cross-border Banking.

The publication of the report at this time is no rushed reaction to the terrorist atrocities and the new urgency for dealing with terrorist finance; rather it is the latest stage in a long process of consideration and development of the committee's thinking on customer due diligence that commenced with the 1988 report, The Prevention of Criminal Use of the Banking System for the Purpose of Money Laundering, which laid down basic ethical principles and sought to encourage banks to introduce customer identification procedures, decline suspicious transactions and assist law enforcement agencies. That report was followed by the Core Principles for Effective Banking Supervision Report in 1997, which called for banks, on the one hand to put in place strict 'know your customer' procedures and, on the other for banking supervisors to encourage banks to adopt appropriate Financial Action Task Force (FATF) recommendations, such as those addressing customer identification, the keeping of records, the detection and reporting of suspicious transactions in addition to procedures for dealing with those countries deemed to have less than adequate anti-money laundering regimes. Subsequently, the 1999 Core Principles Methodology report advanced the process further by identifying essential and additional criteria promoting high ethical and professional standards to prevent banks being intentionally or unintentionally used by criminal elements.

The new Customer Due Diligence for Banks report was commissioned from the Working Group on Cross-border Banking under the joint chairmanship of Charles Freeman, Deputy Secretary General of the Basel Committee, and Colin Powell, Chairman of the Offshore Group of Banking Supervisors and Chairman of the Jersey Financial Services Commission. It stemmed from a 1999 Basel Committee internal survey of cross-border banking that identified deficiencies in 'know your customer' policies for banks in a large number of countries, including variable standards in those countries with well-developed financial markets. The report lays down recommended 'know your customer' standards applicable to all banks in all countries and the Basel Committee envisages it will become the benchmark for banking supervisors to establish national practices and for banks to develop their internal procedures and standards. The report distinguishes its work from that of the FATF as its perspective goes beyond money laundering to a wider prudential perspective that places 'know your customer' procedures as a central and crucial element in the management 
of banking risk. The report highlights the risk that inadequate 'know your customer' due diligence leaves banks vulnerable to reputational, operational, legal and concentration risks that can foreshadow significant financial costs to banks. The report concentrates on four key elements that should be included in all bank customer due diligence programmes: customer acceptance, customer identification, ongoing monitoring of high-risk accounts and risk management.

The report identifies the need for banks to develop customer acceptance policies that effectively identify high-risk customers using factors including background, country of origin, public profile, linked accounts and business activities among those risk factors considered as part of a graduated customer acceptance policy utilising more extensive due diligence in the case of high-risk customers.

The report provides a three-part definition of banking customers as those people or entities that maintain an account with a bank or those on whose behalf an account is maintained; the beneficiaries of transactions conducted by professional intermediaries; and any person or entity connected with a financial transaction who can pose a significant reputational or other risk to the bank. Detailed guidance is provided in the case of certain categories of customer identification which give particular cause for concern: trust, nominee and fiduciary accounts, corporate vehicles, introduced business, client accounts opened by professional intermediaries, politically exposed persons, non-face-to-face customers and correspondent banking.

The report highlights the importance of the ongoing monitoring of accounts and transactions as an essential aspect of 'know your customer' procedures; in particular, an understanding of what constitutes normal account activity and the ability to identify transactions that fall outside the normal patterns of activity associated with a particular account such as high cash deposits, rapid account turnover contrasting with normal account balance and transactions that appear to defy economic or commercial sense. In addition, it highlights the crucial role played in customer due diligence by adequate management information systems supplying the necessary information to identify, monitor and analyse high-risk accounts in a timely manner to senior management and compliance personnel.

The report places emphasis on risk management as an essential element of customer due diligence and calls for effective management oversight, segregation of functions and training. In particular, the report highlights the need for the compliance function within banks to provide an independent critique of the banks' procedures and policies, such as the fulfilment of legal and regulatory obligations. In addition, the report calls for internal audits to assess risk management and controls and to report findings directly to board level.

It seems likely that the Customer Due Diligence report will become increasingly significant for both banks and banking supervisors as the focus on the need to interdict both general criminal and terrorist financial transactions continues in the months and years ahead.

The full report is available on the Bank for International Settlements website: http://www.bis.org/publ/bcbs85.pdf

Paul Clement

IALS Editor

December 2001 